\title{
Pola Konsumsi Suporter Wanita pada Pertandingan Sepak Bola di Kota Malang
}

\author{
Andarwati \\ Jurusan Manajemen Fakultas Ekonomi dan Bisnis Universitas Brawijaya \\ Jl. MT Haryono 165 Malang, Jawa Timur, Indonesia \\ Radityo Handrito, MM \\ Jurusan Manajemen Fakultas Ekonomi dan Bisnis Universitas Brawijaya \\ Jl. MT Haryono 165 Malang, Jawa Timur, Indonesia \\ e-mail: radityohandrito@ub.ac.id \\ Desi Tri Kurniawati, MM \\ Jurusan Manajemen Fakultas Ekonomi dan Bisnis Universitas Brawijaya \\ Jl. MT Haryono 165 Malang, Jawa Timur, Indonesia
}


Andarwati

Radityo handrito, MM

Desi Tri Kurniawati, MM
Jurnal Manajemen Bisnis Indonesia

Vol. 1, Nomor 3, Juni 2014

\section{Pendahuluan}

Olahraga telah menjadi industri yang berkembang dalam dua dasawarsa terakhir. Fenomena tersebut terjadi di seluruh dunia. Olahraga tidak lagi menjadi sebuah aktifitas fisik yang bermanfaat bagi pelakunya, tetapi telah menjadi sebuah hiburan dan komoditas bagi penikmat olahraga. Seperti halnya produk lain, olahraga juga memiliki karakteristik yang berbeda dalam menarik calon konsumen untuk membeli atau mengkonsumsi olahraga. Karena merupakan perpaduan antara jasa hiburan dan barang, industri olahraga perlu memperhatikan selera konsumen mereka.

Menurut Hansen dan Gauthier dalam Neale dan Funk (2005), memahami perilaku dan motivasi suporter untuk meningkatkan pembelian produk olahraga adalah kunci sukses bagi klub olahraga profesional. Salah satu olahraga yang dikenal memiliki suporter fanatik adalah sepak bola. Sebagai olahraga yang paling digemari di dunia, sepak bola memiliki potensi komersial yang besar bagi pelaku usaha. Kehadiran suporter olahraga merupakan potensi pasar yang harus diperhatikan oleh pelaku industri olahraga. Para suporter harus diyakinkan bahwa mereka mendapatkan manfaat dari produk yang mereka konsumsi, yaitu produk olahraga.

Sepakbola identik dengan olahraga kaum laki-laki. Pelaku dan konsumen sepakbola dapat dikatakan mayoritas adalah laki-laki. Sehingga tidak mengherankan jika segala produk yang terkait sepak bola dirancang untuk kebutuhan laki-laki. Akan tetapi dalam kurun waktu 10 tahun terakhir penyelenggaraan liga sepak bola professional di Indonesia, muncul sebuah fenomena hadirnya kaum wanita dalam kegiatan sepakbola, terutama suporter.

Fenomena tersebut menarik untuk diteliti dengan tujuan mengetahui alasan apa yang mendorong para suporter wanita untuk mengkonsumsi produk sepakbola yang identic dengan laki-laki. Jawaban dari fenomena tersebut penting bagi para pelaku industri sepakbola karena dengan hadirnya wanita dalam sepakbola berarti bertambahnya potensi pasar dalam industry.

Meningkatnya kehadiran suporter wanita di stadion berarti meningkatnya penjualan tiket pertunjukan dalam satu pertandingan. Meningkatnya jumlah suporter wanita dapat meningkatkan penjualan merchandise yang diproduksi oleh para apparel. Bagi penyelenggara pertandingan, kehadiran suporter wanita harus diimbangi dengan pelayanan yang mengakomodir kebutuhan suporter wanita. Sedangkan bagi para apparel, hal ini berarti mereka harus menyediakan produk yang memenuhi kebutuhan suporter wanita. Setiap wilayah memiliki ciri karakteristik penduduk yang berbeda-beda sehingga memiliki pola konsumsi yang berbeda pula. Begitu hal nya dengan konsumsi produk sepak bola. Kota Malang dikenal memiliki fanatisme yang tinggi terhadap sepak bola karena memiliki dua klub yang berkompetisi di tingkat nasional dan internasional. Selain itu, banyaknya sekolah sepak bola yang berdiri di Kota Malang merupakan potensi bagi produsen peralatan sepak bola. Data BPS tahun 2012 menunjukkan bahwa jumlah penduduk wanita di Kota Malang sejumlah 51\%. Hal tersebut membuat potensi bisnis di bidang produk olahraga pada kaum wanita cukup tinggi. Dengan latar belakang tersebut, maka peneliti tertarik untuk meneliti faktor apa saja yang mempengaruhi pola konsumsi masyarakat Kota Malang terhadap produk olahraga, khususnya kaum wanita. 
Andarwati

Radityo handrito, MM

Desi Tri Kurniawati, MM
Jurnal Manajemen Bisnis Indonesia

Vol. 1, Nomor 3, Juni 2014

Karena masih jarang literatur maupun penelitian yang mengulas tentang wanita dan konsumsi olahraga, maka peneliti menggunakan pendekatan fenomenologi untuk memahami perilaku kaum wanita tersebut.

\section{Landasan Teori}

Solomon (2009) menyatakan bahwa pemasaran adalah suatu fungsi organisasi dan serangkaian proses untuk menciptakan, mengkomunikasikan, dan menyampaikan nilai kepada pelanggan. Armstrong dan Kotler (2009) menyebutkan secara luas bahwa pemasaran adalah proses sosial dan manajerial dimana individu maupun organisasi menerima apa yang mereka butuhkan dan inginkan melalui menciptakan dan menukar nilai antar satu dengan lainnya. Menurut Hoye (2006) manajemen olahraga muncul karena terjadi kompleksitas terhadap dunia olahraga. Olahraga telah menjadi tontonan jutaan orang di dunia, dari organisasi non-profit menjadi organisasi profit, hingga melibatkan sejumlah besar uang di dalamnya. Olahraga telah menjadi simbol kesuksesan, perayaan, dan kegembirann bagi masyarakat dunia. Manajemen olahraga mempelajari bagaimana mengelola penonton agar membeli tiket, membeli suvenir, membentuk komunitas suporter, dan menerapkan ide-ide bisnis dengan tujuan meningkatkan konsumsi terhadap produk olahraga. (Hoye, 2006).

Menurut Shank (2009), pemasaran olahraga adalah penerapankhusus dari prinsip-prinsip dan proses pemasaran terhadap produk olahraga dannon-olahraga (melalui penyertaan pada kegiatan olahraga).Pemasaran olahraga merupakan bagian dari ilmu pemasaran yang fokus terhadap promosi kegiatan olahraga melalui acara olahraga maupun klub olahraga (Beech et al, 2006). Konsumen adalah individu atau kelompok yang mengkonsumsi barang dan jasa untuk memenuhi kebutuhan dan keinginannya. Menurut Shank (2009) Dalam bidang olah raga konsumen dibedakan menjadi 3 jenis yaitu: Suporter, Pelaku, dan Perusahaan (sponsor). Masing-masing konsumen memiliki motivasi yang berbeda dalam mengkonsumsi olah raga.

Suporter adalah konsumen olahraga yang memperoleh benefit atau keuntungan dengan menonton pertandingan. (Shank, 2009). Mereka hadir dalam pertandingan olah raga untuk memenuhi keinginan. Keinginan suporter dapat bermacam-macam sesuai motivasi yang dimiliki setiap suporter. Maka dibutuhkan penelitian untuk mengetahui motivasi utama suporter dalam menghadiri pertandingan. Konsumsi suporter terhadap olah raga dibuktikan dengan pembelian tiket dan kehadiran mereka dalam pertandingan olah raga.

Motivasi adalah suatu proses yang menyebabkan seseorang untuk bertindak sesuai keinginannya (Solomon,2009). Menurut Teori Ekspektansi, kuat atau lemahnya motivasi seseorang dipengaruhi oleh harapan dan keinginan yang berasal dari dalam diri suatu individu. Motivasi adalah pendorong fundamental dalam perilaku konsumen, hal itu dapat dilihat dari motif yang diarahkan seseorang untuk mencapai sesuatu (Onkvisit, 2007).

\section{Metode Penelitian}

Penelitian ini menggunakan metode kualitatif dengan pendekatan fenomenologi. Menurut Bogdan dan Biklen (2003), metode kualitatif adalah metode yang menggambarkan individu, tempat, dan dialog yang sulit untuk diolah menggunakan pendekatan statistik. Creswell (1998) juga menyatakan bahwa metode kualiatif bertujuan untuk memahami suatu kejadian 
Andarwati

Radityo handrito, MM

Desi Tri Kurniawati, MM
Jurnal Manajemen Bisnis Indonesia

Vol. 1, Nomor 3, Juni 2014

hingga seluruh seluk beluknya dan memahami suatu kejadian berdasarkan sudut pandang pelaku kejadian.

Desain penelitian kualitatif dengan pendekatan fenomenologi di dalam penelitian ini bertujuan untuk memahami sebuah fonomena yaitu pola konsumsi dan perilaku suporter wanita di Kota Malang. Moustakas (1994) menyatakan bahwa fenomenologi fokus pada keseluruhan dengan menganalisis suatu kejadian dari berbagai sudut pandang yang bertujuan untuk menemukan esensi pengalaman pelaku kejadian.

Dalam penelitian ini, tahap-tahap metode fenomenologi menganut struktur yang disampaiakan oleh Creswell (1998), yaitu:

a. Mengidentifikasi kejadian yang menarik

b. Peneliti memahami fondasi filosofis metode fenomenologi.

c. Peneliti harus netral atau bebas dari pendapat pribadi terhadap fenomena tersebut.

d. Pengumpulan data dari pelaku kejadian (partisipan)

e. Partisipan menjawab pertanyaan mengenai kejadian

f. Melakukan analisis data.

Penelitian mengenai perilaku suporter telah banyak dilakukan sebelumnya, namun belum ada yang melakukan penelitian khusus mengenai suporter wanita. Oleh karena itu, perlu dilakukan pendekatan fenomenologi dinilai paling sesuai untuk memahami kehadiran mereka di dalam stadion dan perilaku konsumsinya.

\section{Responden dan Prosedur Pemilihan Responden}

Dalam penelitian ini populasi yang dijadikan responden adalah populasi suporter wanita di Kota Malang. Pemilihan responden dalam populasi menggunakan teknik purposive sampling dengan kriteria suporter wanita yang pernah menghadiri pertandingan sepak bola dan mengkonsumsi produk sepak bola di Kota Malang. Hal ini dilakukan karena responden harus benar-benar pernah memiliki pengalaman mengenai fenomena yang sedang diteliti (Sekaran, 2009). Selain itu responden juga harus mampu menjelaskan dan mengungkapkan perasaannya mengenai pengalaman menghadiri pertandingan sepak bola derta mengkonsumsi produk yang terkait sepak bola di Kota Malang.

Dalam peneilitin kualitatif tidak ada jumlah sample responden yang dipersyaratkan, namun menurut Dukes (1984) jumlah responden handaknya antara 3 sampai 10 orang. Hal ini juga didakatakan oleh Creswell (1998), fenomenologi setidaknya melibatkan 10 orang responden. Dengan jumlah tersebut dinilai cukup untuk menvalidasi data penelitian dan variasi data yang didapatkan. Dalam penelitian ini didapat 7 suporter wanita yang bersedia menjadi responden dan menjalani wawancara dengan tim peneliti.

Proses pemilihan 7 responden tersebut menggunakan teknik snowball yaitu menggunakan rekomendasi setiap responden untuk memilih siapa suporter lain yang layak untuk dijadikan responden. Hal ini dilakukan sebagai upaya validasi data karena responden yang telah diwawancarai pasti memiliki informasi mengenai siapa saja suporter yang layak untuk menjawab pertanyaan-pertanyaan yang telah diajukan. Persyaratan yang digunakan cukup sederhana karena penelitian ini bertujuan untuk mengetahui alasan mengapa mereka hadir di 
Andarwati

Radityo handrito, MM

Desi Tri Kurniawati, MM
Jurnal Manajemen Bisnis Indonesia

Vol. 1, Nomor 3, Juni 2014

stadion dan pengalaman apa yang mereka dapatkan selama mengkonsumsi produk olahraga tersebut.

Responden yang terpilih dihubungi untuk proses wawancara sesuai dengan waktu dan tempat yang disediakan oleh responden. Hal ini dilakukan untuk membuat proses penelitian sealami mungkin sehingga jawaban yang diberikan oleh responden merupakan jawaban jujur dan tanpa tendensi tertentu. Lokasi wawancara juga berada di tempat yang nyaman sesuai keinginan responden agar responden tidak merasa asing. Dalam proses wawancara juga disediakan formulir kesediaan partisipasi dalam wawancara tanpa paksaan dari pihak lain.

Hal ini sejalan dengan apa yang disampaikan oleh Creswell (1998) bahwa penelitian kaulitatif akan lebih bersifat alamai Karena bertujuan menggali informasi dari suatu kejadian yang tidak bisa diukur dengan pendekatan statistik saja.

Proses pemilihan dan wawancara responden dilakukan mulai bulan November- Desember 2013. Peneliti lapang menghubungi seorang suporter wanita yang diketahui pernah dan dikenal loyal hadir di stadion melalui media telepon dan meyakinkan tujuan peneilitian ini. Selanjutnya peneliti menyusun jadwal untuk melakukan wawancara pertama. Dari wawancara pertama dengan responden, didapatkan dua nama suporter wanita lain yang layak untuk dijadikan responden. Proses ini berlanjut sampai responden ke 7.

Dalam setiap wawancara, responden diberikan 25 pertanyaan terstruktur untuk melakukan validasi informasi. Dalam proses menjawab 25 pertanyaan tersebut berkembang pertanyaan lain yang bertujuan untuk menggali lebih dalam mengenai pengalaman responden dalam menghadiri pertandingan dan mengkonsumsi produk sepak bola.

Durasi yang diperlukan dalam setiap wawancara berbeda-beda untuk masing-masing responden tergantung perkembangan jawaban yang diberikan oleh responden. Namun untuk menjawab 25 pertanyaan dasar, diperlukan waktu setidaknya 45-60 menit. Proses wawancara tidak dilakukan terstruktur, namun dilaksanakan sealami mungkin layaknya diskusi informal. Hal ini dilakukan untuk meminimalisir kesan formal yang dikhawatirkan membuat jawaban responden tidak jujur. Selain itu wawancara juga melibatkan responden lain yang mengenal dunia sepak bola agar dapat menggali informasi lebih dalam dari setiap responden.

Setiap pertanyaan yang telah diajukan akan ditanyakan lagi di tengah dan di akhir wawancara untuk konfirmasi dan validasi pernyataan. Validasi transkrip jawaban dilakukan pada beberapa responden melalui email maupun bertemu langsung untmemeriksa hasil transkrip wawancara. Namun karena tidak semua responden bersedia melakukan hal tersebut karena berbagai alasan dan tidak semua responden memiliki akses dan kemampuan teknologi informasi, maka di setiap akhir wawancara, responden diperdengarkan hasil rekaman dan dapat menambahkan atau mengkoreksi jawaban yang diberikan.

\section{Pertanyaan Penelitian}

Penelitian kualitatif dilakukan untuk menjawab pertanyaan penelitian yang muncul dari fakta di lapangan. Dalam penelitian ini, pertanyaan penelitian yang berusaha dijawab adalah:

1. Mengapa wanita Kota Malang mengkonsumsi produk olahraga? 
Andarwati

Radityo handrito, MM

Desi Tri Kurniawati, MM
Jurnal Manajemen Bisnis Indonesia

Vol. 1, Nomor 3, Juni 2014

2. Seberapa besar potensi wanita Kota Malang sebagai pasar produk olahraga?

\section{Analisis Data}

Analisa data dalam penelitian ini menganut saran yang ditulis oleh Creswell (1998) yang terdiri dari empat tahapan utama yaitu: a. analisa data untuk mendapatkan pernyataan inti, $b$. mengartikan pernyataan dan mengkategorikannya berdasarkan kesamaan arti, c. mendeskripsikan fenomena, dan d. menyaring deskripsi menjadi pernyataan fundamental.

Untuk meminimalkan salah intepretasi jawaban responden, transkrip segera dibuat setelah wawancara dilakukan. Hal ini juga dilakukan karena ingatan pewawancara masih baru sehingga setiap kejadian dapat didokumentasikan dengan baik.

Setelah berupa transkrip yang divalidasi oleh responden, tim peneliti membaca transkrip berulang kali untuk memahami dan mengintepretasi masing-masing jawaban. Setelah itu tim peneliti menyampaikan pendapat masing-masing untuk ditulis dalam bentuk deskripsi jawaban responden. Moustakas (1994) menyebutkan bahwa proses mentransformasikan jawaban menjadi pernyataan inti merupakan kewajiban peneliti. Selain itu, proses tersebut juga melalui penggunaan imajinasi, mengumpulkan berbagai referensi, hingga melihat dari sudut pandang, fungsi, dan peran yang berbeda.

Pendapat-pendapat tersebut kemudian dikategorikan berdasarkan tema-tema tertentu sehingga menghasilkan pernyataan fundamental yang menjadi kesimpulan atau hasil dari penelitian.

\section{Hasil}

Kompetisi sepak bola di Indonesia pertama kali digelar pada tahun 1914. Pada saat itu kompetisi hanya dijalankan secara amatir dan masih bersifat kedaerahan. Kompetisi ini dikenal dengan kompetisi perserikatan dan berlangsung hingga tahun 1993. Peserta dari kompetisi ini adalah klub yang mewakili daerah yang ada di Indonesia seperti Surabaya, Jakarta (Batavia), Bandung, Semarang, Solo, Medan, Makassar, dan Yogjakarta. Dalam perkembangan selanjutnya, klub-klub tersebut menjadi milik Pemda setempat dan beroperasi dengan suntikan dana APBD masing-masing daerah.Pada tahun 1979 diperkenalkan kompetisi Galatama (Liga Sepak Bola Utama), yaitu format kompetisi semi profesional yang diikuti oleh klub-klub yang berdiri secara mandiri tanpa suntikan APBD. Galatama berlangsung mulai tahun 1979-1993.Pada tahun 1994, PSSI berinisiatif menyatukan dua kompetisi tersebut menjadi sebuah kompetisi nasional yang diikuti klub-klub terbaik di Indonesia. Sistem kompetisinya berjenjang mulai divisi 3 di setiap propinsi hingga divisi utama tingkat nasional. Kompetisi tersebut dinamakan LIGINA (Liga Indonesia).

Karena berasal dari penggabungan dua format kompetisi, maka pada awal pelaksanaanya, Ligina menggunakan format 2 wilayah (barat dan timur). Wilayah ini didasarkan atas wilayah geografis dan mengakomodir jumlah peserta yang tinggi (18 klub untuk setiap wilayah). Saat ini, Liga Indonesia memasuki musim ke 21. Sejak tahun 2013, kompetisi Liga Indonesia divisi utama disebut dengan Liga Super Indonesia (LSI) dengan format dua wilayah dan sistem peringkat. Sedangkan divisi di bawahnya masih memiliki format yang sama seperti sebelumnya. Karena merupakan kompetisi tertinggi di Indonesia dan memiliki potensi 
keuangan yang sangat besar, pengelolaan kompetisi LSI diarahkan menuju industrialisasi sepak bola dimana seluruh klub yang menjadi peserta LSI harus berbentuk badan hukum PT dan beroperasi layaknya unit bisnis.

Di Kota Malang, sampai tahun 2012 ada dua tim yang berlaga di kasta tertinggi sepak bola Indonesia yaitu Persema dan Arema. Namun sejak tahun 2013 akhir Persema mengalami krisis dan tidak lagi berlaga di kompetisi. Sedangkan Arema masih menjadi salah satu tim kuat di tingkat Nasional. Meskipun Arema bukanlah tim yang dimiliki pemda, tetapi justru Arema yang menjadi ikon kebanggaan warga Malang. Fanatisme tersebut tidak hanya dialami oleh laki-laki, tetapi juga kaum wanita.

\section{Responden}

Dalam penelitian ini terdapat 7 wanita yang bersedia menjadi responden dan mengikuti proses wawancara sampai proses verifikasi jawaban. Untuk memudahkan proses analisa, maka 7 responden tersebut akan diurutkan sesuai kode abjad dari A-J. Berikut adalah responden dalam penelitian ini:

a. Adelia (AD), seorang mahasiswi kedokteran berusia 20 tahun. Responden merupakan warga Kota Malang yang lahir di Kota Jombang Jawa Timur. Mulai mengenal sepak bola dan Arema Cronus sejak tahun 2008. Orang tua Adelia juga tidak berasal dari Kota Malang, Ayah dari Pasuruan dan Ibu dari Jombang.Meskipun bukan kelahiran Kota Malang, responden menyukai klub Arema Cronus dan sering hadir dalam pertandingan di stadion. Responden memiliki pendapatan dari uang saku Rp. 1.500.000 per bulan.

b. Erlita Eka (EE), seorang mahasiswi ekonomi berusia 19 tahun. Responden merupakan warga asli Kota Malang dan mengenal sepak bola dan Arema Cronus sejak kecil. Responden selalu hadir di stadion saat ada pertandingan bersama keluarga. Responden memiliki pendapatan Rp. 600.000 per bulan dari uang saku.

c. Resti (RI), seorang mahasiswi ilmu komunikasi berusia 21 tahun. Responden merupakan warga Kota Malang, namun ayah dari Kediri dan Ibu dari Jombang. Responden tinggal di Malang sejak lahir karena orang tua bekerja di Kota Malang. Responden memiliki pendapatan dari uang saku sebesar Rp. 2.100.000 per bulan.

d. Vita (VA), seorang mahasiswi berusia 22 tahun dan kuliah di salah satu perguruan swasta di Kota Malang. Responden tiggal di Kota Malang sejak janjang SMA. Memiliki pendapatan sebesar Rp. 1.000 .000 per bulan dari uang saku, selalu menonton pertandingan sepak bola di TV maupun di stadion.

e. Matahari (MI), seorang ibu rumah tangga dan wiraswasta berusia 27 tahun. Mantan wartawan salah satu media di Kota Malang dan merupakan warga asli Kota Malang. Pendapatan per bulan Rp. 5-10 juta rupiah. Mengenal Arema sejak jenjang SMA, saat ini hanya menonton pertandingan sepak bola di TV karena masih mengurus bayi.

f. Maulidyah (MA), seorang pegawai bank kelahiran Malang berusia 26 tahun dan sedang bertugas di Purwokerto. Dia selalu menyempatkan diri untuk hadir di Stadion jika jadwal kepulangannya bersamaan dengan jadwal tanding arema. Menjadi fans sejak bangku SMP.

g. Mutmainah $(\mathrm{MH})$, ibu rumah tangga dengan 3 orang anak. Responden adalah warga Kepanjen dan sudah sering menonton pertandingan arema sejak Stadion Kanjuruhan menjadi home base arema. Alasan menonton adalah menemani suami dan anak. 
Andarwati

Radityo handrito, MM

Desi Tri Kurniawati, MM
Jurnal Manajemen Bisnis Indonesia

Vol. 1, Nomor 3, Juni 2014

\section{Jawaban Responden}

Berdasarkan hasil transkrip wawancara yang diperoleh, maka jawaban-jawaban responden dapat dikategorikan menjadi bagian dan sub bagian yang akan digunakan dalam proses analisa. Kategori jawaban didasarkan pada teori bauran pemasaran jasa karena pada dasarnya yang dikonsumsi oleh para responden adalah jasa hiburan, meskipun tidak seluruhnya murni jasa. Langkah ini dilakukan untuk menjaga pola analisis agar selalu sesuai dengan teori dasar mengenai pemasaran jasa. Selain itu, jawaban juga dirangkum menurut pertanyaan untuk memudahkan tabulasi dan mendukung hasil analisa.

Menurut konsep bauran pemasaran jasa, ada 7 hal yang dikonsumsi oleh konsumen yaitu:

\section{a. Produk}

Karena termasuk produk jasa dengan kombinasi barang (fisik), maka penggambaran produk dari sebuah tontonan pertandingan merupakan kesatuan dari seluruh aspek dalam pertandingan dan juga tidak dapat terlepas dari motivasi seorang penonton. Kombinasi dari seluruh aspek tersebut dapat menentukan tingat kepuasan bagi setiap penonton.

Produk utama dari sebuah pertandingan sepak bola adalah tontonan yang berupa olahraga yang dilakukan oleh dua tim dalam lapangan selama 2x 45 menit. Akan tetapi, produk tontonan tersebut memiliki durasi yang relatif pendek dan tidak dapat disimpan dalam waktu yang lama, meskipun ada perangkat elektronik yang dapat melakukan itu.

Dalam industri olahraga, konsumen memiliki konsep yang berbeda-beda mengenai sebuah produk. Pada awalnya, suporter memandang produk utama dari pertandingan adalah penampilan tim yang sedang bertanding, sehingga kualitas produk tergantung dari kemampuan tim dalam meraih kemenangan. Jika tim yang dibela kalah, maka seluruh kualitas produk dianggap buruk dan kepuasan konsumen tidak tercapai.

Permasalahan yang muncul dalam bidang jasa adalah bagaimana menggantikan produk gagal dan memberikan kepuasan pada konsumen saat produknya sudah "habis" dan tidak dapat diproduksi ulang. Oleh karena itu pelaku industri jasa berupaya memperluas definisi produk dengan menciptakan produk lain yang terkait dengan tontonan.

Dalam industri olahraga sepak bola, produk utama dapat dinikmati dengan baik jika ada produk penunjang yang baik pula. Produk-produk tersebut antara lain: kondisi dan lokasi stadion tempat pertandingan dilaksanakan, pelayanan selama menonton pertandingan, hingga merchandise klub. Dalam penelitian ini produk yang dikonsumsi oleh konsumen adalah tontonan pertandingan antara Arema dengan tim lawan, kondisi stadion Kanjuruhan, pelayanan panitia pelaksana pertandingan, makanan-minuman yang dijual di stadion, dan merchandise klub Arema (Kaos, syal, topi, dll).

Dalam kasus suporter sepak bola, seluruh kualitas produk masih sangat ditentukan oleh kualitas tim. Jika tim bermain baik dalam satu pertandingan atau satu musim, maka kualitas produk lain akan dianggap baik pula tanpa melihat jenis bahan bakunya dan suporter cenderung membeli tanpa melakukan pertimbangan. Sebaliknya, jika tim bermain jelek hingga menduduki posisi terbawah dari klasemen, maka keseluruhan 
Andarwati

Radityo handrito, MM

Desi Tri Kurniawati, MM
Jurnal Manajemen Bisnis Indonesia Vol. 1, Nomor 3, Juni 2014

produk akan dianggap jelek dan penjualan produk akan cenderung menurun. Akan tetapi kondisi tersebut akan berbeda jika suporter memiliki fanatisme tinggi terhadap klub.

Dalam penelitian ini yang menjadi fokus penelitian adalah konsumen wanita yang mengkonsumsi sebuah produk dengan alasan yang berbeda. Dari hasil wawancara dapat diketahui bahwa produk yang dikonsumsi oleh suporterwanita bukan kualitas permainan atau skill pemain, tetapi interaksi sosial yang tercipta di stadion atau selama perjalanan ke stadion. Hal ini didukung oleh jawaban responden:

- "ya ke stadion karena seru"

- "Di stadion rame, beda sama di TV"

- "Bisa liat atraksi suporter"

- "Bisa liat pemain yang ganteng langsung"

- "sekalian nganter anak dan suami nonton"

\section{b. Harga}

Komponen selanjutnya yang menentukan sebuah layanan jasa adalah harga. Produk jasa yang tidak dapat disimpan dan tak berwujud membuat konsumen selalu membandingkan satu jasa dengan jasa yang lain terutama dari segi harga. Harga dapat dijadikan pedoman mengenai kualitas dari suatu produk. Harga yang tinggi cenderung diasosiasikan dengan kualitas yang baik.

Akan tetapi, dalam industri sepak bola, harga tidak selalu menjadi patokan utama, meskipun tetap menjadi pertimbangan bagi sebagian orang. Mahal atau murahnya tiket suatu pertandingan di suatu kota, tidak bisa didasarkan pada harga tiket di kota lain, tetapi dibandingkan dengan daya beli msayarakat di daerah tersebut. Di kota Malang, harga Rp. 100.000 untuk kelas VIP dianggap mahal untuk pertandingan sepak bola, sedangkan di kota Jakarta dengan harga Rp. 100.000 hanya mendapatkan kelas tribun utama.

Dalam sebuah pertandingan, harga tiket menunjukkan jenis kelas atau tribun menonton. Panitia pelaksana pertandingan Arema mencetak tiga jenis kelas dengan harga yang berbeda yaitu: Ekonomi dengan harga Rp. 50.000, VIP dengan harga Rp. 100.000, dan VVIP dengan harga Rp 150.000.

Perbedaan yang didapat dari tiga kelas tersebut adalah posisi tribun, ekonomi di tribun tanpa atap, VIP tribun dengan atap, VVIP tribun dengan atap dan posisi di tengah bagian atas. Sehingga perbedaan kelas tersebut hanya mengenai kenyamanan menonton pertandingan, karena pertandingan sepak bola hanya memiliki satu jenis setiap pertandingan.

Bagi suporterwanita, kelas VIP dan VVIP merupakan pilihan utama. Selain karena keamanan yang lebih baik, suasana yang didapat lebih nyaman dibandinkan dengan kelas ekonomi. Apalagi bagi suporter ibu-ibu yang tujuan utamanya adalah mengantar keluarga. Hal ini yang dialami oleh MH pada setiap pertandingan.

"Saya datang ya karena nganter suami dan anak yang hobi bola, ngurusi makanan sama minuman. Enak di VIP soale gak panas dan gak hujan, kaya rekreasi lah..." 
Hal tersebut juga senada dengan jawaban responden lain mengenai kelas VIP yaitu:

" mahal sih, tapi enak di VIP, gak panas",

"kalo di ekonomi banyak cowoknya, jingkrak-jingkrak gak bisa nonton. Ya beli yang mahal dikit gak apa-apa",

" di VIP bisa duduk enak"

“ di ekonomi biasane ada yang mabuk, jadi bikin gak nyaman"

Dari pernyataan tersebut dapat disimpulkan bahwa suporter wanita akan memilih harga yang tinggi asalkan mendapat pelayanan yang lebih baik. Bagi pengelola pertandingan hal ini merupakan potensi bisnis yang sangat besar asalkan ditunjang dengan fasilitas dan jaminan keamanan yang lebih baik.

\section{c. Lokasi/Distribusi}

Lokasi penyediaan jasa merupakan komponen penting dalam industri olahraga sepak bola. Karena proses produksi dan konsumsi yang terjadi bersama, maka lokasi pertandingan sepak bola merupakan elemen penting dalam suatu pertandingan. Arema menggunakan stadion Kanjuruhan sebagai lokasi bertanding. Stadion Kanjuruhan terletak di Kota Kepanjen Kabupaten Malang yang berjarak $20 \mathrm{Km}$ dari Kota Malang. Sebelum tahun 2004, Arema menggunakan stadion Gajayana yang ada di Kota Malang. Namun karena kapasitas stadion yang tidak mencukupi, maka Arema pindah ke stadion Kanjuruhan yang memiliki kapasitas lebih besar.

Pada awalnya, pemindahan lokasi pertandingan sejauh $20 \mathrm{~km}$ cukup berdampak bagi suporter. Namun dalam waktu 4 tahun terakhir, lokasi tersebut tidak lagi menjadi halangan bagi suporter untuk hadir di stadion. Bahkan memberikan kesempatan bagi warga Kabupaten untuk dapat hadir dalam pertandingan. Dengan fasilitas transportasi dan akses jalan yang semakin baik, perjalanan dari Kota Malang ke Kota Kepanjen dapat ditempuh kurang dari satu jam dan relative mudah dijangkau, sehingga kehadiran suporter ke stadion juga semakin meningkat. Bagi suporter wanita yang berdomisili di Kota Malang, lokasi stadion Kanjuruhan memang cukup menyulitkan. Mereka hanya akan berangkat jika bersama teman atau keluarga dan memiliki fanatisme yang besar. Hal ini senada dengan jawaban yang diberikan oleh responden:

"Ya gimana lagi mas, di (Kota) Malang stadionnya gak cukup lagi”

“Gpp mas, kan gak tiap hari ke Kepanjen (lokasi stadion Kanjuruhan”

“ Kalo pertandingan sore masih diusahakan berangkat, tapi kalo malem gak boleh sama orang tua"

Produk tontonan sepak bola selain sesi pertandingan adalah sesi latihan tim. Jika pertandingan berlokasi di Kabupaten Malang, sesi latihan biasanya digelar di Stadion Gajayana. Pada saat sesi latihan suporter dapat menonton dan berinteraksi dengan 
pemain. Maka bagi suporter yang tidak bisa hadir di pertandingan, biasanya datang pada saat latihan.

Produk sampingan Arema adalah merchandise klub yang dapat diperoleh di berbagai lokasi di Kota Malang. Produk tersebut tidak diproduksi sendiri oleh Arema, melainkan oleh UKM yang ada di Kota Malang. Klub Arema mendapatkan keuntungan dengan menjual stiker lisensi untuk setiap unit produk. Dengan banyaknya lokasi penjualan, konsumen dengan mudah mendapatkan merchandise klub di Kota Malang termasuk suporter wanita. Menurut responden, lokasi penjualan merchandise sudah cukup banyak, tetapi beberapa lokasi justru mengganggu ketertiban. Hal ini harus menjadi perhatian bagi pengelola klub maupun pemerintah daerah.

" kostum beli di City of Arema Klojen mas, lengkap"

"beli di depan stadion, murah mas cuma buat sekali-sekali aj kok"

“di pasar besar banyak, tapi harga ne gak standar, kadang malah ganggu orang jalan”

\section{d. Promosi}

Kegiatan promosi dalam industri olahraga sepak bola, lebih mengarah kepada promosi produk sponsor daripada promosi produk klub. Setiap area yang ada di stadion maupun bagian kostum pemain menjadi media promosi bagi sponsor. Dalam setiap kegiatan promosinya, klub sepak bola justru menampilkan logo, merek, yang menjadi daya tarik dari produk sponsor. Sebaliknya, produk klub justru tidak dipromosikan.

Di Indonesia belum ada sebuah klub yang mempromosikan produknya sendiri. Yang telah dilakukan hanya pengumuman mengenai jadwal pertandingan suatu klub. Hal ini terjadi karena klub sulit untuk mengemas produk apa yang dapat dipromosikan kepada calon konsumen. Bahkan beberapa kalangan berpendapat bahwa produk sepak bola hanya ditujukan pada suporter atau penggemar bola saja, sehingga tidak perlu promosi kepada masyarakat.

Perlu diperhatikan bahwa saat ini konsumen pertandingan dan produk olahraga sudah berkembang. Produk olahraga tidak terbatas hanya pada tontonan, tetapi juga meliputi fasilitas tontonan, makanan-minuman, merchandise, dan hiburan lainnya. Saat ini olahraga dapat dikategorikan sebagai jasa hiburan, oleh karena itu pesaingnya bukan hanya dari industri olahraga tetapi juga dari jasa hiburan lain. Jasa tontonan olahraga harus dapat menjadi alternatif produk hiburan bagi konsumen. Oleh karena itu pelaku industry olahraga harus menciptakan suatu produk dan mempromosikan pada konsumen.

Dengan hadirnya suporter wanita di stadion, pelaku industry olahraga sepak bola harus menciptakan suatu produk yang dapat mengakomodir kebutuhan suporter wanita. Berdasarkan wawancara yang dilakukan, suporter belum pernah tahu jika ada promosi mengenai produk Arema selain pengumuman jadwal pertandingan. 
Andarwati

Radityo handrito, MM

Desi Tri Kurniawati, MM
Jurnal Manajemen Bisnis Indonesia Vol. 1, Nomor 3, Juni 2014

\section{e. Proses}

Proses produksi suatu tontonan dimulai dari proses perizinan sampai pembersihan stadion. Suatu pertandingan dapat digelar jika sudah dijadwalkan oleh otoritas liga dan memperoleh ijin dari phak keamanan. Dalam pertandingan sepak bola, selain menjadi konsumen, suporter juga merupakan bagian dari proses produksi. Baik buruknya pertandingan juga dapat dipengaruhi oleh perilaku suporter, oleh karena itu panitia pelaksana pertandingan harus mampu mengelola kehadiran suporter dan membuat mereka menjadi bagian dari produk tontonan yang baik.

Proses penyelenggaraan pertandingan dapat berjalan selama 2-3 hari bahkan bisa mencapai 1 minggu menyesuaikan laga yang digelar. Proses produksi permainan yang disebut latihan tim bahkan berjalan setiap hari. Sedangkan suporter hanya hadir di stadion antara 3-6 jam saja. Oleh karena itu penting bagi panitia pelaksanan untuk memberikan pertunjukan yang baik hanya dalam waktu yang singkat.

Dalam suatu pertandingan, suporter dapat mempengaruhi proses produksi, termasuk suporter wanita. Keberadaan suporter wanita membuat panitia pelaksana pertandingan harus menyiapkan fasilitas, tenaga keamanan, dan petugas pertandingan khusus wanita. Perlakuan terhadap wanita tentunya berbeda dengan perlakuakn terhadap laki-laki, oleh karena itu membutuhkan proses yang berbeda pada saat pertandingan. Akan tetapi, banyak suporter yang tidak mengetahui keseluruhan proses dalam suatu pertandingan. Proses yang dapat dinikmati oleh suporter adalah saat memasuki stadion, pertandingan berjalan, dan saat keluar stadion.

Pertama, saat memasuki stadion, suporter menginginkan akses masuk yang nyaman dan tidak berdesak-desakan. Bagi suporter wanita, berdesak-desakan merupakan hal yang tidak menyenangkan dan harus dihindari. Kejadian berdesak-desakan biasa terjadi di kelas ekonomi dan saat pertandingan besar. Untuk menghindari hal tersebut para suporter wanita biasanya memilih di kelas VIP yang cenderung lebih tertib. Hal ini didukung oleh pernyataan responden:

“ enak di VIP, masuk e gampang. Gerbang e di depan stadion jadi gak muter-muter"

"kalo di ekonomi sering digodain orang-orang pas masuk gerbang"

Kedua, saat pertandingan berlangsung. Proses permainan di atas lapangan adalah proses yang disaksikan oleh seluruh penonton termasuk suporter wanita. Kebanyakan suporter wanita hanya memahami pada saat terjadi gol tau adanya pelanggaran. Diluar itu, biasanya mereka hanya menikmati suasana atau focus pada hal tertentu seperti pemain, atraksi suporter, dan suasana stadion. Hal ini didukung pernyataan responden:

" enak lihat di stadion, bisa teriak-teriak pas gol"

"di stadion bisa liat pemain langsung"

“gak ngerti (peraturan), yang penting seru liat rame-rame aksi suporter" 
Ketiga, adalah saat keluar stadion suporter harus sabar antri untuk keluar stadion karena seluruh suporter pulang pada saat yang sama. Stadion Kanjuruhan hanya memiliki 1 gerbang utama sebagai akses masuk stadion, sehingga membuat proses tersebut berjalan lambat. Jalan menuju stadion pun hanya dua lajur sehingga menimbulkan kemacetan setiap pertandingan.

\section{f. SDM/ People}

Penyelenggaraan pertandingan tidak terlepas dari SDM yang dimiliki oleh klub dan panitia pelaksana pertandingan. SDM dari klub merupakan inti dalam proses produksi pertandingan. Kualitas sebuah pertandingan ditentukan oleh kemenangan. Klub dengan pemain dan pelatih baik akan menghasilkan kemenangan yang mengindikasikan kualitas yang baik. Sebaliknya, jika tim tidak menghasilkan kemenangan maka seluruh kinerja tim dinilai buruk.

Oleh karena itu, setiap klub akan berusaha merekrut pelatih dan pemain yang memiliki kemampuan terbaik untuk menghasilkan produk yang baik. Jika penampilan klub baik maka kehadiran suporter juga semakin meningkat dan pada akhirnya meningkatkan profit klub. Selain menghasilkan kinerja tim yang baik, keberadaan pemain idola juga dapat meningkatkan kehadiran suporter di stadion atau meningkatkan penjualan merchandise klub. Keberadaan pemain bintang merupakan daya tarik sebuah klub bagi suporter. Selian melihat kemampuan bermain bola, suporter juga melihat fisik dari seorang pemain, terutama suporter wanita.

Bagi suporter wanita yang tidak semuanya memahami peraturan pertandingan, keberadaan pemain idola merupakan daya tarik tersendiri. Hal tersebut juga terjadi di seluruh dunia, misalnya saat LA Galaxy merekrut David Beckham dan Real Madrid merekrut Chistiano Ronaldo. Selain memiliki kemampuan yang handal, pemain-pemain tersebut direkrut karena memiliki potensi menarik perhatian suporter wanita.

Bagi suporter Arema, kehadiran pemain bintang seperti Gonzales, merupakan daya tarik tersendiri meskipun Gonzales sudah berkeluarga. Akan tetapi factor tersebut merupakan alasan bagi sebagain suporter wanita untuk hadir di stadion. Hal ini didukung oleh jawaban responden:

"alasan ke stadion yak arena pengen lihat pemain yang ganteng"

"aku dulu suka Franco Hitta, sekarang suka Gonzales.. ganteng sih"

Oleh karena itu, penting bagi sebuah tim untuk memiliki pemain yang dapat menarik animo masyarakat yang awam terhadap sepak bola, termasuk wanita. Meskipun tujuan mereka hanya melihat pemain, tetapi kedatangan mereka ke stadion tetap mendatangkan pendapatan bagi panitia pelaksana pertandingan.

\section{g. Bukti fisik}

Bukti fisik merupakan dampak dari konsumsi sebuah produk jasa. Bukti fisik juga dapat berfungsi sebagai perpanjangan dari produk jasa yang tidak berwujud dan memiliki durasi 
Andarwati

Radityo handrito, MM

Desi Tri Kurniawati, MM
Jurnal Manajemen Bisnis Indonesia Vol. 1, Nomor 3, Juni 2014

konsumsi yang relative singkat. Keberadaan bukti fisik dapat menegaskan dan mengingatkan konsumen akan sebuah produk jasa.

Dalam produk tontonan pertandingan, bukti fisik yang dapat dikonsumsi oleh suporter antara lain: fasilitas stadion, makanan-minuman dalam stadion, dan merchandise klub.

Sebagai bagian dari proses produksi, fasilitas stadion memegang peranan penting dalam suatu pertandingan. Stadion yang memiliki fasilitas baik akan memuaskan suporter yang hadir di pertandingan. Pertandingan sepak bola hanya berjalan 2 x 45 menit saja, namun suporter sudah hadir di stadion 2 atau 3 jam sebelum peetandingan dimulai. Maka dalam rentang waktu tersebut, suporter mengkonsumsi apa yang tersaji dalam stadion. Jika dalam rentang waktu tersebut suporter tidak mendapatkan kenyamanan, maka akan berdampak pada kualitas produk secara keseluruhan. Apalgi jika tim yang didukung kalah, maka keseluruhan produk akan dinilai buruk oleh suporter.

Bagi suporter wanita, keberadaan fasilitas yang mengakomodir keperluan wanita sangatlah penting. Berbeda dengan suporter laki-laki, suporter wanita lebih mencari kenyamanan lokasi daripada kualitas permainan. Meskipun ada beberapa suporter wanita yang paham mengenai pertandingan, tetapi mereka masih memilih lokasi paling nyaman untuk menonton. Hal ini dapat dibuktikan dengan jumlah suporter wanita yang memilih menonton di kelas VIP atau VVIP dibandingkan di kelas ekonomi. Hal ini didukung pernyataan:

" di VIP ada kamar mandinya mas, meskipun masih campur tapi lebih bersih daripada yang di ekonomi”

"di VIP banyak yang jual makanan dan gampang belinya"

" bisa foto-foto, kalo di ekonomi susah"

\section{Simpulan}

Berdasarkan kategori hasil jawaban dan interpretasi jawaban responden, maka peneliti mengemukakan analisa bahwa:

a. Olahraga, termasuk sepak bola, telah bermetamorfosis menjadi sebuah hiburan bagi masyarakat. Hal ini merujuk pada pengertian olahraga yang awalnya hanya aktivitas fisik seseorang yang dilakukan untuk tujuan pribadi menjadi aktivitas fisik yang dapat dikonsumsi oleh banyak orang berupa tontonan dan keseruan dalam menyaksikan olahraga. Dengan menjadi sebuah hiburan, maka industry olahraga harus berkembang mengikuti selera konsumen, terutama untuk olahraga yang bersifat massa seperti sepak bola.

Industri hiburan selalu mengikuti keinginan konsumen, olahraga yang awalnya mementingkan kesehatan saja, sekarang harus memperhatikan estetika dan euphoria penonton.

Unsur kesenangan (enjoyment) menjadi penting bagi olahraga massa karena menjadi daya tarik dalam setiap pertandingan. Hal ini dapat dilihat pada olahraga sepak bola, 
basket, American football, base ball, dan rugby. Bahkan olahraga otomotif seperti F1 pun mempertimbangkan faktor tersebut dalam setiap musimnya.

b. Fakta bahwa sepak bola yang awalnya merupakan olahraga khas laki-laki juga telah berubah menjadi olahraga yang diminati oleh kaum wanita. Keterlibatan kaum wanita dalam sepak bola tidak hanya sebatas sebagai penonton, tetapi juga sebagai pelaku dan sebagai pengelola sepak bola. Hal yang sama juga terjadi dalam basket.Fenomena tersebut menandakan bahwa olahraga tidak lagi dapat dibedakan berdasar jenis kelamin, tetapi harus bersifat universal dan diterima oleh berbagai pihak.

Dalam menyasar segmen wanita, olahraga harus menunjukkan sisi maskulin karena motivasi suporter wanita dalam menghadiri pertandingan olahraga laki-laki adalah melihat sisi maskulin dari olahraga tersebut. Keberadaan pemain yang atletis, tampan, dan berbakat adalah salah satu cara yang digunakan oleh klub dalam meraih pendapatan dari kaum wanita.

Dalam penelitian juga didapatkan fakta bahwa kehadiran suporter wanita dalam pertandingan sepak bola disebabkan karena ajakan teman maupun keluarga. Pelaku industri sepak bola harus mempertimbangkan peran teman maupun keluarga untuk mempengaruhi kaum wanita agar mau hadir di pertandingan sepak bola.

Berdasarkan hasil analisa dan pemahaman mendalam di maka ada beberapa hal yang menjadi jawaban atas pertanyaan penelitian dan temuan dalam penelitian ini, antara lain:

a. Kehadiran suporterwanitadilatarbelakangi oleh motivasi yang berbeda dengan suporter laki-laki. Oleh karena itu, klub maupun panitia pelaksana pertandingan harus memahami produk apa yang diinginkan dan sesuai bagi kaum wanita yang ingin menyaksikan pertandingan sepak bola.

b. Pola konsumsi suporter wanita berbeda dengan suporter laki-laki, sehingga membutuhkan perlakuaan yang berbeda terutama factor keamanan dan kenyamanan. Potensi bisnis hadirnya suporter wanita Kota Malang dalam pertandingan olahraga belum cukup besar karena kehadiran mereka masih dipengaruhi oleh lingkungan sekitar. Hanya sebagian yang sudah memiliki motivasi pribadi untuk hadir di pertandingan. Namun dengan hadirnya mereka di stadion menunjukkan bahwa mereka membutuhkan produk yang mampu memenuhi kebutuhan mereka selama menonton pertandingan.

\section{Diskusi}

Berdasarkan fenomena suporter wanita di Kota Malang, maka diketahui bahwa para suporter memiliki alasan atau motivasi yang berbeda dengan suporter laki-laki dalam mengkonsumsi produk olahraga. Pola konsumsi suporter wanita dipengaruhi oleh faktor eksternal yaitu keluarga dan teman. Belum semua suporter wanita menjadi pembuat keputusan pembelian terhadap produk olahraga sepak bola. Frekuensi konsumsi suporter wanita juga belum stabil dalam setiap musim. Dengan hasil penelitian tersebut perlu dilakukan penelitian lanjutan untuk mengkonfirmasi apakah fenomena serupa yang terjadi di daerah lain juga dilatar belakangi oleh faktor-faktor yang sama.

Bagi dunia industri, dengan melihat potensi yang ada pada suporter wanita, selayaknya klub sebagai produsen harus mampu memetakan dan menyediakan produk apa saja yang sesuai dengan keinginan kaum wanita selain produk tontonan utama. 
Andarwati

Radityo handrito, MM

Desi Tri Kurniawati, MM
Jurnal Manajemen Bisnis Indonesia Vol. 1, Nomor 3, Juni 2014

\section{Daftar Pustaka}

Armstrong, Gary and Phillip Kotler, 2009, Marketing: An Introduction.,New Jersey: Prentice Hall.

Beech, John, Simon Chadwick, 2006, The Marketing of Sport. New Jersey: Prentice Hall.

Bogdan, R.C. dan Biklen, S.K. 2003. Qualitative Research for Education: An Introduction to Theory and Methods. Fourth Edition. Needham Heights, MA: Allyn dan Bacon.

Creswell, John W. 1998. Qualitative Inquiry and Research Design: Choosing among Five Traditions. Thousand Oak: Sage Publication

Funk, Daniel C, Kevin Filo, Anthony A Beaton, Mark Pritcahrd, 2009, Measuring the Motives of Sport Attendance: Bridging the Academic-Practicioner Divide to Understanding Behavior. Sport Marketing Quarterly, Vol 18/3, pp 126-138.

Funk, Daniel C, D.F Nakazawa, M Hirakawa, 2001, Development of Sport Interest Inventory: Implication for Measuring Unique Consumer Motives at Sporting Event. International Journal of Sport Marketing and Sponsorship 3, 291-316.

Hoye, Russel, Aaron Smith, Hans Westerbeek, Bob Stewart, Matthew Nicholson, 2006, Sport Management: Principle and Application, Oxford: Elsevier

Kim, Jun Woo, Jeffrey D James, Yu Kyoum Kim, 2013, A model of the relationship among sport consumer motives, spectator commitment, and behavioral intentions, Sport Management Review 16, 173-185.

Kotler, Phillip, Kevin Lane Keller, 2009, Marketing Management, New Jersey: Prentice Hall.

Malhotra, Naresh K, 2010, Marketing Research: An Applied Orientation. $6^{\text {th }}$ Edition,New Jersey: Prentice Hall.

Moustakas, Clark, Phenomenological Research, 1994, Sage Publication.

Neale, Larry and Daniel C Funk, 2005, Fan Motivation and Loyalty: Extending The Sport Interest Inventory (SII) to The Australian Football League, ANZMAC 2005 Conference: Sport, Art, and Heritage Marketing.

Sekaran, Uma, 2009, Metodologi Penelitian Bisnis, Jilid 2, Jakarta: Salemba Empat.

Shank, Matthew D, Sport Marketing, 2009, $4^{\text {th }}$ Edition, New Jersey: Prentice Hall.

Sloan, L. R. (1989). The motives of sports fans. In J. H. Goldstein (Ed.), Sports, games, and play: Social and psychological viewpoints (2nd ed., pp. 175-240). Hillsdale, NJ: Lawrence Erlbaum Associates.

Solomon, Michael R, 2009, Consumer Behavior: Buying, Having, Being $8^{\text {th }}$ Edition, New Jersey: Prentice Hall. 
Trail, G. T., \& James, J. D. (2001). The motivation scale for sport consumption: Assessment of the scale's psychometric properties. Journal of Sport Behavior, 24(1),108-127. 